\title{
Mangrove Conservation Strategy in Bedono Village, Sayung District, Demak Regency Based on Remote Sensing Satellite Data
}

\author{
Atmari $^{1, *}$, Denny Nugroho Sugianto ${ }^{2}$, and Fuad Muhammad $^{3}$ \\ ${ }^{1}$ Master Program in Environmental Science, Faculty of Postgraduate Studies, Diponegoro University, Semarang - Indonesia \\ ${ }^{2}$ Department of Oceanography, Faculty of Fisheries and Marine Sciences, Diponegoro University, Semarang - Indonesia \\ ${ }^{3}$ Department of Biology, Faculty of Science, Mathematics, Diponegoro University, Semarang - Indonesia
}

\begin{abstract}
The mangrove ecosystem is an ecosystem unit in the form of a stretch containing biological natural resources dominated by trees that grow in coastal areas and river estuaries and is influenced by tides. The purpose of this study was to determine the vegetation in Bedono Village, Sayung District, Demak Regency by using remote sensing technology for conservation. Remote sensing technology has recently been used by government agencies or non-government agencies because it is considered more effective and efficient. Based on remote sensing data, the mangrove ecosystem in Bedono Village, Sayung Subdistrict, Demak Regency experienced an increase in the category of moderate and heavy mangroves in 2004-2009.
\end{abstract}

Keywords: Mangrove; conservation; remote sensing; vegetation.

\section{Introduction}

Indonesia is an archipelagic country that has a wealth of abundant natural resources, one of which is mangrove forest. Mangrove forests are one of the three important ecosystems in coastal areas besides coral reefs and seagrasses. Mangrove forests are coastal forest ecosystems consisting of groups of trees that can live in environments with high salinity. Mangrove forests are one type of woody plant that grows along protected tropical and sub-tropical coastlines and has a coastal landform of anaerobic soil type. The area of mangrove ecosystems in Indonesia reaches $75 \%$ of the total Southeast Asian mangroves, and from around 15,900 million ha of existing mangrove forests in the world, around $23 \%$ or around $3,489,140.68$ ha [1]. This number represents $23 \%$ of the world's total mangrove ecosystem [2]. As a dynamic coastal ecosystem, mangroves have the ability to adapt to respond to changes in the environment. When the water level rises, the mangrove will move towards the ground and form new zoning. One form of mangrove adaptation is its ability to bind sediments. Both sediments from upstream and those carried by the tide.

Climate change due to global warming like lately can trigger sea level rise or often called SLR (Sea Level Rise) and become one of the factors that influence mangrove vegetation. Global warming is not the only cause of sea level rise. In general, the causes of sea level rise can be divided into three factors, namely (a) global (b) regional (c) local. Changes in sea level due to global factors are the main factors that are worrying at the moment because it will cause low coastal plains to be submerged. Regional factors are generally caused by tectonic activity in a region, while local factors that occur are subsidence as a result of changes in soil mass and underground fluid changes. The impact of sea level rise and climate change will affect a very wide sector in the coastal region. The sectors and areas that are heavily affected are generally natural systems and man-made systems. Natural systems include various landforms and ecosystems, such as sandy beaches, rocky beaches, cliffs, tidal plains, coral reefs and wetlands including mangroves. If the existence of an ecosystem cannot be maintained anymore, then coastal abrasion often occurs due to the absence of wave retention. Pollution from the sea river because there is no filter for pollutants and cultivation activities will be threatened by itself.

The connection with the existence of mangrove ecosystems is currently threatened by the consequences of climate change, the rise in sea level, exploitation of mangrove forests into firewood and land conversion that causes degraded mangrove forests. One technology that can be used to see the development of mangrove forests is by remote sensing technology. Remote sensing satellites can provide the information needed for the process of classification and mapping of natural resources. The distribution and density of mangroves can be identified by remote sensing technology where the geographical location of different mangroves in the land

Corresponding author: atmari.official $@$ gmail.com 
and sea transitional regions provides a distinctive recording effect when compared to other vegetation objects [3]. Therefore, this study was conducted to determine the mangrove vegetation on the north coast, Sayung Subdistrict, Demak Regency.

\section{Literature Review}

\subsection{Mangrove Forest}

The word "mangrove" is a blend of Portuguese mangue which means plant and English grove which means thicket or small forest. Mangrove forest is a forest that mainly grows on alluvial sludge in coastal areas and tidal estuaries which are influenced by sea tides and consists of Avicennia, Rhizophora, Bruguiera, Ceriops, Sonneratia, Lumnitzera, Excoecaria, Xylocarpus trees, Scyphyphora, and Nypa [4].

If the mangrove forest is viewed from the discussion, it consists of two syllables, namely "forest" and "mangrove". According to law No. 41/1999 and Law No. 19/2004 which regulates forestry, the forest is an ecosystem unit in the form of a stretch of land containing biological natural resources which are dominated by trees in the fellowship of their natural environment, which cannot be separated from one another [5]. Whereas the word mangrove is forest vegetation that grows between tidal lines, but it can also grow on coral shores, on dead coral plains on which is covered with a thin layer of sand or covered with mud or muddy beaches [6].

\subsection{Functions of Mangrove}

Mangroves play a key role in protecting the coast from the brunt of waves, winds, and storms. Mangrove stands can protect settlements, buildings, agriculture from strong winds or seawater intrusion. Ecologically it plays a key role in nutrient turnover or elements in the surrounding coastal waters which are aided by the movement of tides. The interaction of mangrove vegetation with its environment is able to create climate conditions that are suitable for the continuation of the biological processes of various aquatic organisms. The next role of mangroves is as river and coastal bank stabilizers that provide growth dynamics in coastal areas, such as controlling coastal erosion, maintaining the stability of sediments and contributing to adding land building and protecting agents [7].

\subsubsection{Biota Habitat}

The mangrove ecosystem is the habitat of aquatic and terrestrial biota. Aquatic biota includes shrimp, fish, crabs, shellfish and various other invertebrates. While terrestrial biota that generally occupies the upper part of the mangrove tree includes groups of insects, primates, reptiles, and aveses groups.

\subsubsection{Spawning Ground, Nurturing and Foraging}

Mangroves include a distinctive ecosystem, as a place to find food (feeding ground), spawning (spawning ground), nursery (nursery ground) a variety of aquatic and terrestrial fauna. Mangrove ecosystems are a suitable place for aquatic biota to spawn and raise their children. In addition to providing space for the biota to hide, the roots of mangrove plants also destroy sea waves and currents so that eggs and fish children are not washed away by ocean currents or ocean waves. In relation to food availability, mangrove ecosystems are places that are rich in food sources for aquatic biota in the form of organic material formed from falling leaves and dirt of land animals which are then converted by microorganisms into bioplankton which is needed by marine biota.

\subsubsection{Supporting Marine}

Ecosystems Mangrove ecosystems are ecosystems that are located between land and sea so that they have a function as a buffer for land and sea. The basic components of the food chain in the mangrove ecosystem are litter (leaves, twigs, fruit, and stems) which fall in decomposition by microorganisms into nutrients or dissolved nutrients that can be utilized directly by phytoplankton, algae and mangrove plants themselves in the process of photosynthesis. Litter produced by mangrove plants includes $\mathrm{N}$ and $\mathrm{P}$ which is high and will dissolve in water so that it can support the life of phytoplankton. Phytoplankton as the main producer of water fixes carbon through photosynthetic processes while providing energy to consumer organisms. In the next tropic level, the primary consumer will act as a food source for secondary consumers and so on. If the process goes well, it is the carrying capacity of the mangrove ecosystem towards fisheries production through its function as a provider of energy sources and habitats [8].

\subsubsection{Coast Protectors}

Tight and fixed mangrove rooting can reduce waves and waves. Large winds and storms will decrease when reaching dense mangrove forests. Damage to the waves will be reduced by mangrove forests. Mangrove ecosystems are also effective for capturing soil particles and sediments from land erosion. The particles and mud carried by water from the land will be trapped by the roots of the mangrove and precipitate it will become thicker and will become a new land towards the sea. The existence of mangrove ecosystems in coastal areas becomes a buffer against seawater intrusion. Dense and dense mangrove ecosystems can prevent the entry of seawater from underground to land.

\subsection{Damage to the Mangrove}

Ecosystem Indonesia's mangrove ecosystem continues to decline. Based on data released by BAKOSURTANAL 
(National Survey and Mapping Coordinating Board) in 2009 [9] that the area of mangrove forests in Indonesia reached 3.2 million. The data was obtained using the approach of the Lansat remote sensing satellite imagery recorded between 2006 and 2009 and added with the latest reference data from each data source [9].

Damage to mangrove ecosystems is caused by several natural factors such as natural disasters, climate change or global warming. One of the effects of global warming is the rise in sea level or often called SLR (Sea Level Rise). The sea level rise in the coastal environment and small islands will have a broad impact not only from the environmental side but also on the social and economic side. Non-natural factors such as exploitation of mangrove forests into fuel wood, charcoal, pollution and the most dominant are the conversion of mangrove land into fishponds, shrimp ponds and clearing of mangrove land into settlements [10].

The supporting factors that cause the destruction of mangrove forests include economic growth which requires transportation facilities and infrastructures such as roads, terminals, ports, and urbanization so as to accelerate the occurrence of damage [11].

\subsection{Strategies for Management and Preservation of Mangrove Forests Mangrove}

Forest management has two main concepts that can be applied namely protection of mangrove forests and rehabilitation of mangrove forests. One way that can be done in an effort to protect mangrove forests is to designate one mangrove area to be a conservation area, a green belt along the coast and a sungi edge [8]. The strategy for preserving mangroves is a very complex activity and community involvement is needed to achieve these goals. The fundamental purpose of managing mangrove ecosystems is to improve conservation, rehabilitation and sustainable use of mangrove ecosystems [12].

\section{Research Methods}

This research is a literature study on mangrove vegetation in the northern coastal area of Sayung Subdistrict, Demak Regency, which is sourced from the reference of a research journal about remote sensing of mangrove vegetation, relevant books, and sources. Data can be presented descriptively and analyzed so that it can be developed into a scientific study [13].

\section{Results and discussion}

Coastal areas are transitional areas between land and sea which have high levels of biological productivity. Bedono Village, Sayung Subdistrict, Demak Regency is located at positions $06^{0} 55^{\prime} 44^{\prime} \mathrm{LS}$ and 110²9'42 'BT' 14. Here are the boundaries of the Bedono Village:

- Next to the utata : Java Sea to

- The South : Terjsloko Village to
- The West :Sido Gemah Village and Purwosari Village

- East : Sriwulan Village

This coastal area is prone to the danger of flooding caused by rising sea levels due to global warming. Mangrove ecosystems have a significant role in protecting the coast from the brunt of waves, winds and storms. Mangrove stands can protect settlements, buildings, agriculture from strong winds or sea water intrusion. Ecologically it plays a key role in nutrient turnover or elements in the surrounding coastal waters which are aided by the movement of tides. The interaction of mangrove vegetation with its environment is able to create climate conditions that are suitable for the continuation of the biological processes of various aquatic organisms.

Mangrove ecosystems in the northern coastal region of Bedono Village, Sayung District, Demak Regency are based on remote sensing data carried out by [15] as follows.

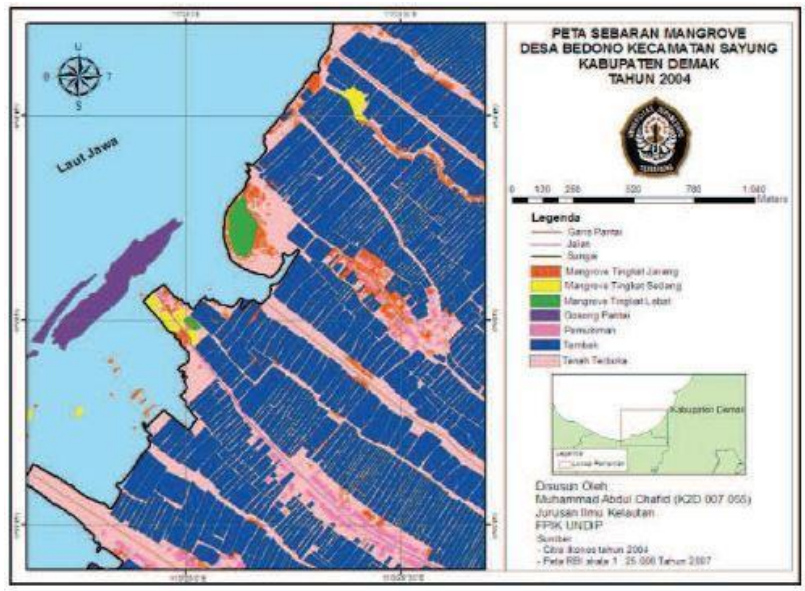

Fig. 1. Bedono mangrove area in 2004

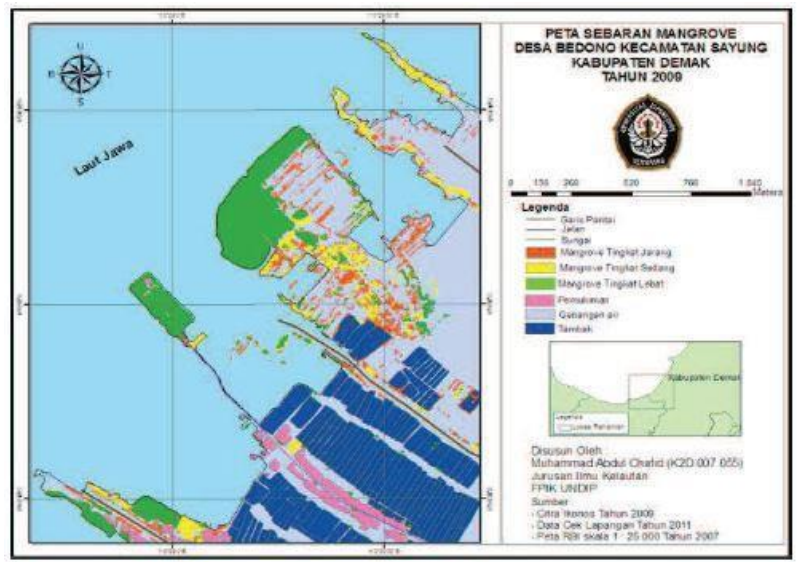

Fig. 2. Bedono mangrove area in 2009 


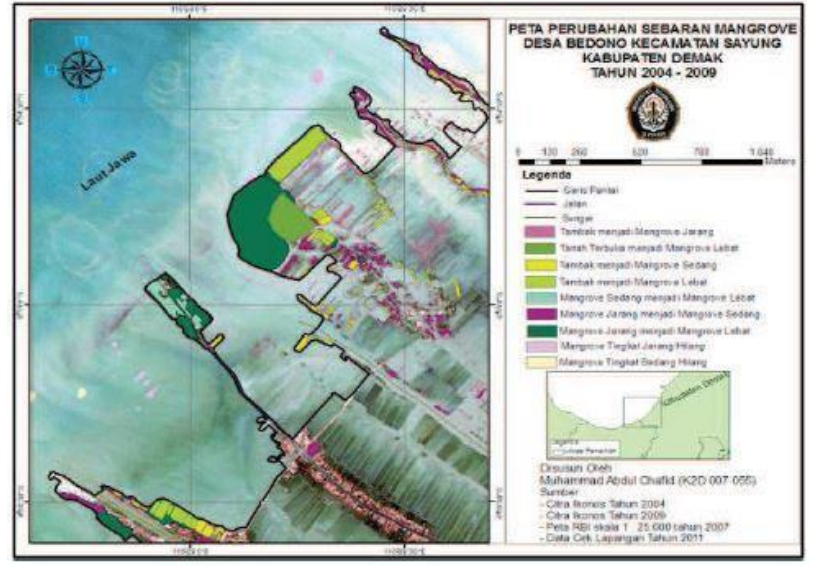

Fig. 3. Bedono mangrove area in 2004 - 2009

Table 1. Mangrove area has a density level in 2004 2009 Bedono Village, Sayung Sub-district

\begin{tabular}{|c|c|c|c|}
\hline \multirow{2}{*}{$\begin{array}{c}\text { Density } \\
\text { Level }\end{array}$} & \multicolumn{2}{|c|}{ Area (ha) } & Change (ha) \\
\cline { 2 - 4 } & 2004 & 2009 & $2004-2009$ \\
\hline Rarely & 14.94 & 7.08 & -7.86 \\
\hline Moderate & 2.41 & 8.89 & $+6,48$ \\
\hline Lebat & 5.06 & 27.06 & +22 \\
\hline Amount of & 22.41 & 43.03 & \\
$\begin{array}{c}\text { Description: } \\
+=\text { Increased }\end{array}$ & $-=$ Decreased
\end{tabular}

From the results of remote sensing observations in Bedono Village, Sayung District as in fig. 1, fig. 2 and fig. 3 of mangroves in Bedono Village is categorized into 3 namely rare mangroves, moderate mangroves and dense mangroves. The area of mangroves in the village of Bedono in 2004 - 2009 has increased in the category of moderate and dense mangroves, as seen in table 1 . While in the category of mangroves it rarely decreased by 7.8 ha. This condition can be caused by the nature and characteristics of mangroves, namely mangroves capable of capturing soil particles and sediments from land erosion. The particles and mud carried by water from the land will be trapped by the mangrove roots and settle so that it will form a new land longer. As for changes in the density of mangrove areas, rarely as Table 1 can be caused by natural factors. Conservation and rehabilitation activities are very important to restore mangrove forests affected. The involvement of the surrounding community for the process of mangrove forest rehabilitation is needed to keep the mangrove forest maintained

\section{Conclusion}

Mangrove ecosystem in Bedono Village, Sayung Subdistrict, Demak Regency is divided into three categories: rare mangroves, medium mangroves, and dense mangroves. Extent of expansion in medium and heavy levels of mangrove in 2004-2009.

\section{Refereces}

1. Ministry of Environment and Forestry in 2015.

2. C. Giri, E. Ochieng, L.L. Tieszen, Z. Zhu, A. Singh, T. Loveland, N. Duke, Status and Distribution of Data Using Earth Observation Satellite Data, Global Ecology and Biogeography 20(1), 154-159 (2011)

3. A. Faizal, M.A. Amran, Effective Vegetation Index Transformation Model for the Prediction of Mangrove Density Rhizophora mucronata, PIT MAPIN XIV ITS (2005)

4. Soerinegara, Concern the Determination of the Width of the Green Line of Mangrove Forests. Proceedings of Seminar III Mangrove Ecosystem. Jakarta (1987)

5. Law of the Republic of Indonesia No. 41/1999 About Forestry

6. C. Saparinto, Utilization of the Mangrove Ecosystem, Dahara Prize Publisher, Semarang Indonesia (2007)

7. Ghufran, Kordi, Mangrove Ecosystem, Jakarta: Rineka Cipta (2012)

8. Begen, Dietrich, Introduction and Management of Mangrove Ecosystems, PKSPL-IPB (2001)

9. Bakosurtanal, Indonesian Mangrove Map. Marine Resources Survey Center, National Survey and Mapping Coordination Agency (2009)

10. D. Chandra, H. Frananda, Utilization of Lansat 8 Image for Mapping the Mangrove Ecosystem in Padang City, Georafflesia 3(1), 57-58 (2018)

11. C. Kusmana, Mangrove Ecology, Faculty of Forestry TheIPB (2002)

12. Ministry of Maritime Affairs and Fisheriesin 2005

13. R. Haris, Diversity of Vegetation and Wildlife of Mangrove Forests, Bionature Journal 15(2) (2014)

14. M.P. Putri, Hydro-Oceanographic Characteristics and Levels of Community Participation in Overcoming Coastal Damage in Bedono Village, Sayung District, Demak Regency, Journal of Maquaares 3(4) (2014)

15. M.A. Chafid, R. Pribadi, A. Anugroho, Study of Changes in Mangrove Land Area in Bedono Village, Sayung District, Demak Regency Using Ikonos Satellite Images in 2005 and 2009, Journal of Marine Research 1(2) (2012) 